\title{
Mapa conceptual Derecho Romano Clásico
}

Conceptual Roman Law Classic Map

\section{María P. Fernández-Cuevas ${ }^{a}$}

\section{Abstract:}

In a graphic way, the form of government, the political institutions, the important facts and the sources of law that took place during the classic era of Roman Law in the High Empire are presented.

\section{Keywords:}

Classical law, dynasties and institutions

\section{Resumen:}

De una manera gráfica se presenta la forma de gobierno, las instituciones políticas, los hechos importantes y las fuentes de derecho que privaron durante la época clásica del Derecho Romano en el Alto imperio.

\section{Palabras Clave:}

Derecho clásico, dinastías e instituciones 


\section{Derecho Romano Clásico}

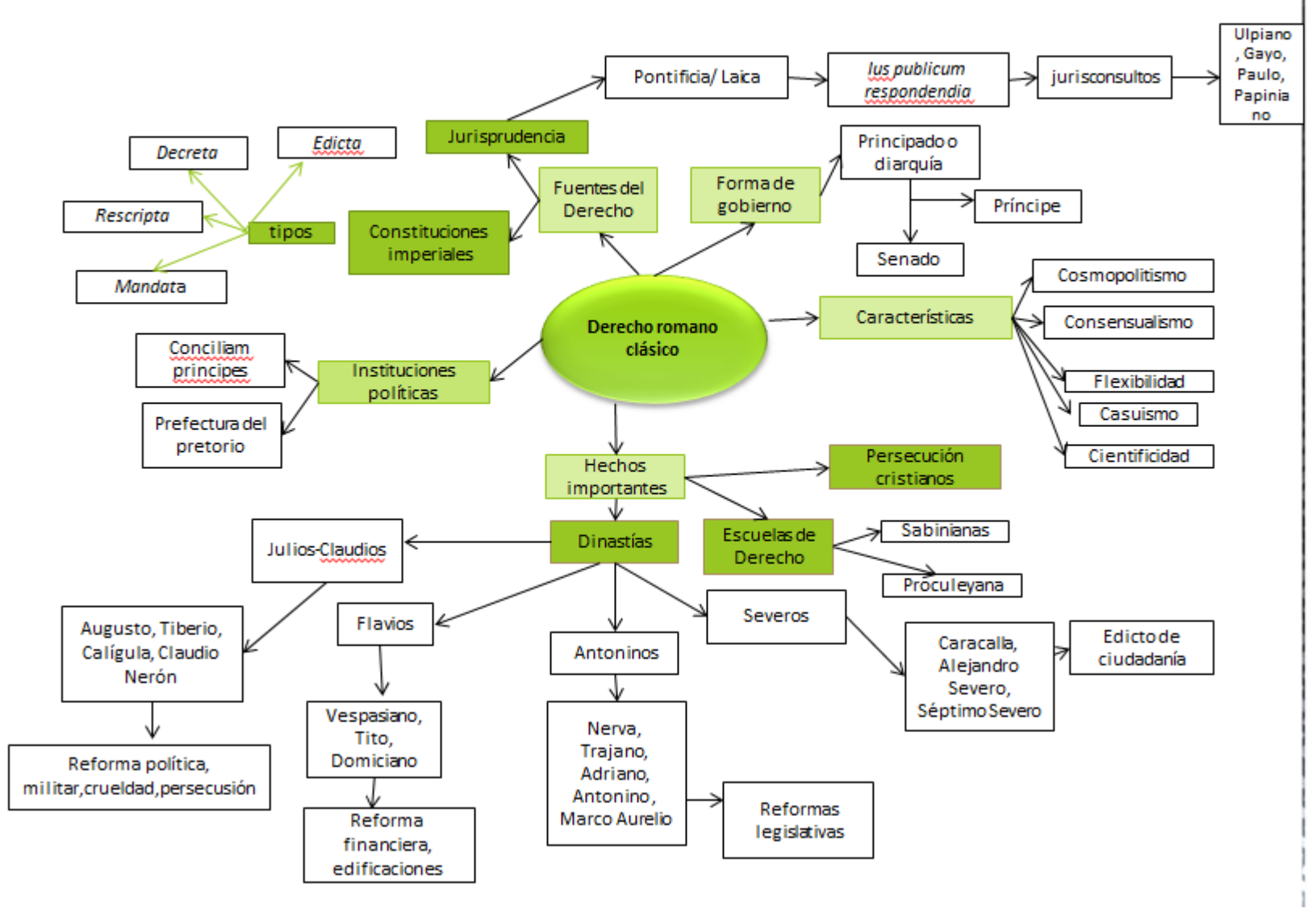

\section{REFERENCIAS}

Bernal, Beatriz, Ledesma José de Jesús. (2010). Historia del Derecho Romano y de los Derechos Neorromanistas. Porrúa. México

Morineau Iduarte, Marta., Iglesias González, Román. (2009). Derecho Romano. Porrúa. México

Petit, Eugéne. (1991). Derecho Romano. Porrúa. México 